\title{
Phase transitions in copper(II) orthovanadate
}

\author{
N SURESH RAO and O G PALANNA* \\ *Department of Chemistry, St Philomena College, Puttur 574 202, India \\ MS received 19 June 1992; revised 10 May 1993
}

\begin{abstract}
Data on the polymorphs of copper(II) orthovanadate are reported. $T$ he $\mathrm{Cu}_{3} \mathrm{~V}_{2} \mathrm{O}_{8}$ phase synthesized in this laboratory exhibits phase transitions between $460^{\circ}$ and $560^{\circ} \mathrm{C}$. These phase transitions are identified through detailed DTA and high temperature XRD techniques; it is observed that these structural transitions are rapid and reversible. The crystal structure of $\mathrm{Cu}_{3} \mathrm{~V}_{2} \mathrm{O}_{8}$ is similar to that of $\mathrm{Mg}_{3} \mathrm{~V}_{2} \mathrm{O}_{8}, \mathrm{Zn}_{3} \mathrm{~V}_{2} \mathrm{O}_{8}, \mathrm{Co}_{3} \mathrm{~V}_{2} \mathrm{O}_{8}$ and $\mathrm{Ni}_{3} \mathrm{~V}_{2} \mathrm{O}_{8}$.
\end{abstract}

Keywords. Polymorph; phase transition; crystal structure.

\section{Introduction}

A variety of copper(II) vanadates of the general formula $n \mathrm{CuO}: \mathrm{V}_{2} \mathrm{O}_{5}$, where $n=1,2,3$ or 5 , were obtained by the conventional solid state reaction technique (Brisi and Molinari 1958; Riassento 1958; Fluery 1966, 1969; Raveau 1967). Polymorphism amongst copper compounds may be more a rule than an exception. It was found that $\mathrm{CuV}_{2} \mathrm{O}_{6}$ (Galy 1976) and $\mathrm{Cu}_{2} \mathrm{~V}_{2} \mathrm{O}_{7}$ (Fluery 1966, 1969; Palanna and Suresh Rao 1993) exhibited phase transitions, upon increasing the temperature, to related crystal structures reversibly depending on their history of synthesis. Although Calvo and Shannon (1972) were not able to prepare crystals of the $\mathrm{Cu}_{3} \mathrm{~V}_{2} \mathrm{O}_{8}$ phase reported by Brisi and Molinari (1958), they were able to synthesize a new form of $\mathrm{Cu}_{3} \mathrm{~V}_{2} \mathrm{O}_{8}$ at elevated pressures. The $\mathrm{Cu}_{3} \mathrm{~V}_{2} \mathrm{O}_{8}$ phase obtained by Calvo and Shannon (1972) is monoclinic $P 2_{1} / C$ which is similar to $\mathrm{Mg}_{3} \mathrm{~V}_{2} \mathrm{O}_{8}$ (Calvo and Krishnamachari 1971), $\mathrm{Zn}_{3} \mathrm{~V}_{2} \mathrm{O}_{8}$ (Calvo and Gopal 1971), $\mathrm{Co}_{3} \mathrm{~V}_{2} \mathrm{O}_{8}$ and $\mathrm{Ni}_{3} \mathrm{~V}_{2} \mathrm{O}_{8}$ (Calvo et al 1973).

Considerable interest has been generated in investigation of the possibility of structural modifications of $\mathrm{Cu}_{3} \mathrm{~V}_{2} \mathrm{O}_{8}$ because Calvo and Shannon (1972) observed that: (i) the presence of a high percentage of electronegative copper (1.9) in $\mathrm{Cu}_{3} \mathrm{~V}_{2} \mathrm{O}_{8}$ resulted in an average $\mathrm{V}-\mathrm{O}$ distance of $1.725 \AA$ in the $\mathrm{VO}_{4}$ tetrahedron of the lattice, which is greater than the $1.720 \AA$ in vanadates containing highly electropositive cations; they also indicated that the $\mathrm{VO}_{4}$ tetrahedron is distorted with distances varying from 1.670 to $1.798 \AA$; (ii) the distortion from the orthorhombic (cmca) crystal structure to monoclinic crystal symmetry $P 2_{1} / C$ of $\mathrm{Cu}_{3} \mathrm{~V}_{2} \mathrm{O}_{8}$ is ascribed to the Jahn-Teller effect typical of $\mathrm{Cu}^{2+}$ ions in the crystal lattice of $\mathrm{Cu}_{3} \mathrm{~V}_{2} \mathrm{O}_{8}$. To date, there are no data available on the polymorphs of copper(II) orthovanadate.

This prompted us to investigate and identify the possible phase transitions by DTA and high temperature XRD techniques. In this paper, we describe new data on the polymorphs of copper(II) orthovanadate, $\mathrm{Cu}_{3} \mathrm{~V}_{2} \mathrm{O}_{8}$. 


\section{Experimental}

\subsection{Preparation of $\mathrm{Cu}_{3} \mathrm{~V}_{2} \mathrm{O}_{8}$ sample}

The copper(II) orthovanadate was prepared by the conventional solid state reaction technique, by heating an intimate mixture $3 \mathrm{CuO}: \mathrm{V}_{2} \mathrm{O}_{5}$ (both of high purity grade) in an atmosphere of air at $750^{\circ} \mathrm{C}$ for five days. The sample was melted in air, and the molten mass of $\mathrm{Cu}_{3} \mathrm{~V}_{2} \mathrm{O}_{8}$ was then cooled $\left(8^{\circ} \mathrm{C}\right.$ per min) slowly in air to room temperature.

\section{$2.2 X$-ray diffraction studies}

The sample synthesized was characterized by $\mathrm{X}$-ray powder diffraction technique using $\mathrm{CuK}_{\alpha}$ radiation $(\lambda=1.5410 \AA$, Ni filter $)$. The high temperature XRD studies were made on an MRC attachment to a Philips diffractometer using $\mathrm{CuK}_{\alpha}$ radiation. The sample was maintained at each temperature for about $15 \mathrm{~min}$. A Pt-Pt $13 \% \mathrm{Rh}$ thermocouple was used for measuring the temperature of the sample.

\subsection{Differential thermal analysis}

The differential thermal analysis (DTA) was done using a fabricated unit and was recorded in a strip chart recorder of high sensitivity. The following conditions were maintained during the DTA run: (i) sample holder, $\mathrm{Pt}$; (ii) reference material, $\mathrm{Al}_{2} \mathrm{O}_{3}$; (iii) heating rate, $8^{\circ} \mathrm{C}$ per min; and (iv) atmosphere, static air.

\section{Results and discussion}

The DTA results of $\mathrm{Cu}_{3} \mathrm{~V}_{2} \mathrm{O}_{8}$ phase are presented in figure 1. On heating the $\mathrm{Cu}_{3} \mathrm{~V}_{2} \mathrm{O}_{8}$ phase in an atmosphere of air, DTA (curve 1) shows an endotherm at $510^{\circ} \mathrm{C}$ accompanied by a knee at $545^{\circ} \mathrm{C}$. On cooling the above phase, exotherms were observed at $532^{\circ} \mathrm{C}$ and $435^{\circ} \mathrm{C}$ (curve 2). It appears, therefore, that $\mathrm{Cu}_{3} \mathrm{~V}_{2} \mathrm{O}_{8}$ undergoes phase transformation upon increasing the temperature.

The XRD pattern of $\mathrm{Cu}_{3} \mathrm{~V}_{2} \mathrm{O}_{8}$ at $25^{\circ} \mathrm{C}$ agrees with the ones reported earlier (Brisi and Molinari 1958; Riassento 1958; ASTM card file No 16-417) with strong reflections at $d(\AA) 3.10,3.12,2.56$ and 2.80 respectively (table 1$)$. To confirm the structural modifications of $\mathrm{Cu}_{3} \mathrm{~V}_{2} \mathrm{O}_{8}$, high temperature $\mathrm{X}$-ray diffractograms were recorded between $25^{\circ}$ and $630^{\circ} \mathrm{C}$ at intervals of $50^{\circ} \mathrm{C}$. The $\mathrm{X}$-ray diffractograms were recorded only after maintaining the sample for $15 \mathrm{~min}$ at a particular temperature during heating/cooling of the sample. Representative portions of X-ray diffractograms of $\mathrm{Cu}_{3} \mathrm{~V}_{2} \mathrm{O}_{8}$ phase at $25^{\circ}, 478^{\circ}$ and $630^{\circ} \mathrm{C}$ are shown in figure 2. Calvo and Shannon (1972) pointed out that $\mathrm{Cu}_{3} \mathrm{~V}_{2} \mathrm{O}_{8}$ phase decomposed at $725^{\circ} \mathrm{C}$, while Fluery $(1966$, 1969) noticed that the decomposition temperature was $780^{\circ} \mathrm{C}$. In contrast to these reports, our results show that $\mathrm{Cu}_{3} \mathrm{~V}_{2} \mathrm{O}_{8}$ is a stable compound which decomposes neither at $725^{\circ}$ nor at $780^{\circ} \mathrm{C}$. We have observed in our DTA investigation that $\mathrm{Cu}_{3} \mathrm{~V}_{2} \mathrm{O}_{8}$ phase melts at $780^{\circ} \mathrm{C}$ (not shown). The XRD characterization of $\mathrm{Cu}_{3} \mathrm{~V}_{2} \mathrm{O}_{8}$ reveal that the sample synthesized is a single phase and stable throughout the 


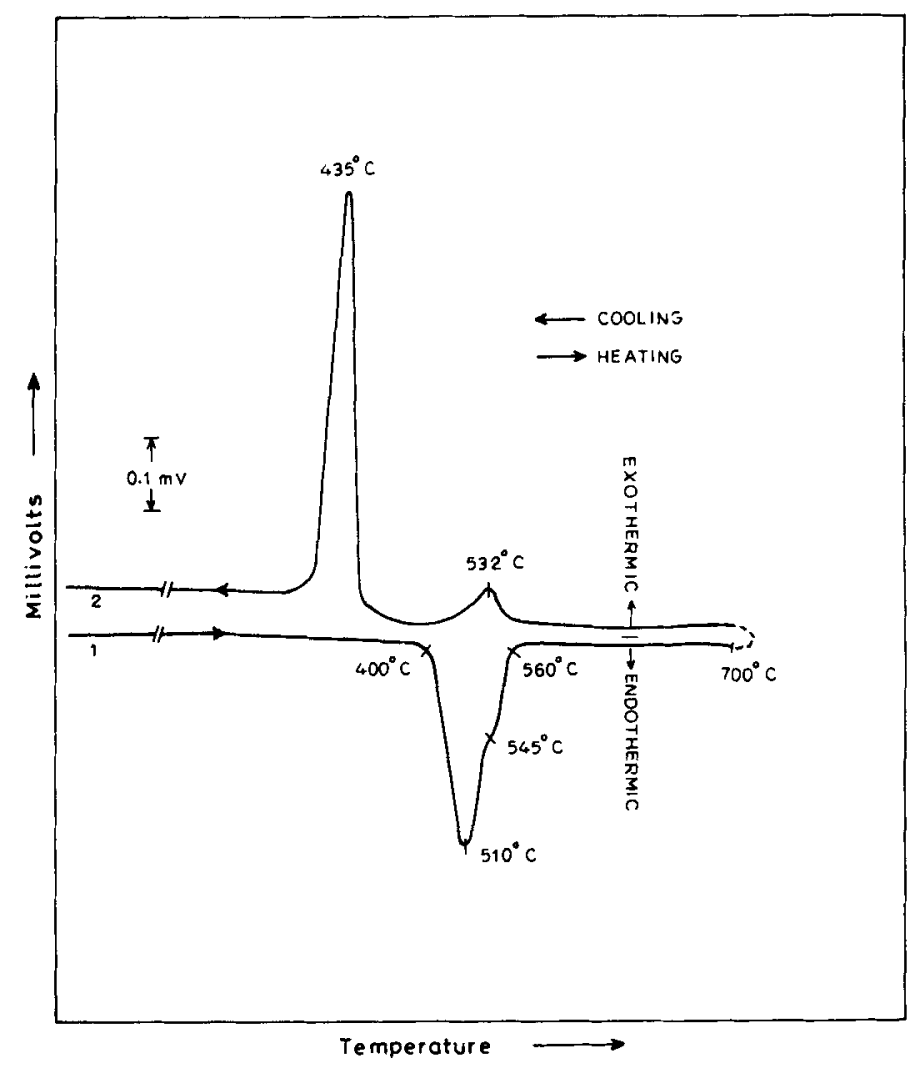

Figure 1. DTA curves for $\mathrm{Cu}_{3} \mathrm{~V}_{2} \mathrm{O}_{8}$ in air.

experimental conditions, since XRD of the phase showed the absence of characteristic XRD intensity peaks of the following kinds: copper(II) vanadates $\mathrm{CuV}_{2} \mathrm{O}_{6}$ (ASTM Card file No 16-127), $\mathrm{Cu}_{2} \mathrm{~V}_{2} \mathrm{O}_{7}$ (Fluery 1966, 1969; Palanna and Suresh Rao 1993), $\mathrm{Cu}_{4} \mathrm{~V}_{2} \mathrm{O}_{9}$ (ASTM Card file No 16-420) and $\mathrm{Cu}_{5} \mathrm{~V}_{2} \mathrm{O}_{10}$ (Brisi and Molinari 1958).

We have noted interesting characteristics from the representative portions of high temperature XRD patterns, as shown in figure 2(1) to 2(3): the strong XRD intensity of the peaks at $3.10,3.12,2.56$ and $2.80 \AA$ decreased gradually upon increasing the temperature; and at $478^{\circ} \mathrm{C}$, a new intensity peak appeared at $2.69 \AA$, followed by other additional equally prominent intensity peaks at $3.24 \AA, 2.16 \AA$ and so on (figure $2(2)$ ). As is evident, the decrease in intensity of peaks at $3.10,3.12,2.56$ and $2.80 \AA$ with temperature is accompanied by the growth characteristics $(2.69,3.24,2.81,2.57,3.10$, 3.13 and $2.16 \AA$ ) of a high temperature modification of $\mathrm{Cu}_{3} \mathrm{~V}_{2} \mathrm{O}_{8}$ at $478^{\circ} \mathrm{C}$. From figure $2(3)$ it is evident that the intense peak at $2.69 \AA$ characteristic of high temperature phase $\left(478^{\circ} \mathrm{C}\right)$ vanished and peak at $2.82 \AA$ became more intense than those at 3.10 , $3.15,3.24$ and $2.57 \AA$. This indicates the possibility of yet another high temperature structural form of $\mathrm{Cu}_{3} \mathrm{~V}_{2} \mathrm{O}_{8}$ at $630^{\circ} \mathrm{C}$. The XRD results also reveal that the phase transitions of $\mathrm{Cu}_{3} \mathrm{~V}_{2} \mathrm{O}_{8}$ are reversible.

Thus the high temperature XRD results confirm and corroborate our DTA results for $\mathrm{Cu}_{3} \mathrm{~V}_{2} \mathrm{O}_{8}$. The XRD of $\mathrm{Cu}_{3} \mathrm{~V}_{2} \mathrm{O}_{8}$ phases are given in table 1. The DTA and XRD 
Table 1. XRD data for $\mathrm{Cu}_{3} \mathrm{~V}_{2} \mathrm{O}_{8}$ at $25^{\circ} \mathrm{C}, 478^{\circ} \mathrm{C}$ and $630^{\circ} \mathrm{C}$.

\begin{tabular}{|c|c|c|c|c|c|}
\hline \multicolumn{2}{|c|}{$\alpha-\mathrm{Cu}_{3} \mathrm{~V}_{2} \mathrm{O}_{8}$ at $25^{\circ} \mathrm{C}$} & \multicolumn{2}{|c|}{$\beta-\mathrm{Cu}_{3} \mathrm{~V}_{2} \mathrm{O}_{8}$ at $478^{\circ} \mathrm{C}$} & \multicolumn{2}{|c|}{$\gamma-\mathrm{Cu}_{3} \mathrm{~V}_{2} \mathrm{O}_{8}$ at $630^{\circ} \mathrm{C}$} \\
\hline$\AA$ & $I / I_{0}$ & $\AA$ & $I / I_{0}$ & $\AA$ & $I / I_{0}$ \\
\hline 5.90 & 12 & - & - & 5.86 & 15 \\
\hline $4 \cdot 23$ & 16 & $4 \cdot 23$ & 10 & $4 \cdot 00$ & 15 \\
\hline 3.97 & 20 & 3.90 & 15 & $3 \cdot 52$ & 10 \\
\hline $3 \cdot 12$ & 60 & 3.55 & 25 & $3 \cdot 24$ & 75 \\
\hline $3 \cdot 10$ & 100 & $3 \cdot 24$ & 60 & $3 \cdot 15$ & 80 \\
\hline 2.89 & 10 & $3 \cdot 13$ & 30 & $3 \cdot 10$ & 95 \\
\hline $2 \cdot 80$ & 70 & $3 \cdot 10$ & 35 & 2.82 & 100 \\
\hline $2 \cdot 62$ & 70 & 2.90 & 10 & 2.64 & 64 \\
\hline $2 \cdot 56$ & 85 & 2.82 & 40 & 2.57 & 60 \\
\hline $2 \cdot 45$ & 25 & 2.69 & 100 & $2 \cdot 42$ & 40 \\
\hline $2 \cdot 42$ & 32 & 2.62 & 50 & $2 \cdot 32$ & 42 \\
\hline 2.41 & 40 & 2.57 & 30 & $2 \cdot 24$ & 30 \\
\hline $2 \cdot 30$ & 30 & 2.46 & 10 & 2.23 & 25 \\
\hline $2 \cdot 16$ & 15 & 2.42 & 20 & $2 \cdot 16$ & 50 \\
\hline $2 \cdot 12$ & 20 & 2.33 & 20 & $2 \cdot 15$ & 45 \\
\hline 1.99 & 30 & $2 \cdot 16$ & 40 & 2.00 & 30 \\
\hline 1.93 & 40 & 2.03 & 10 & 1.94 & 60 \\
\hline 1.84 & 12 & 2.00 & 15 & 1.91 & 24 \\
\hline 1.81 & 15 & 1.95 & 40 & 1.83 & 25 \\
\hline 1.78 & 15 & 1.90 & 10 & 1.78 & 25 \\
\hline 1.67 & 12 & 1.82 & 10 & 1.60 & 20 \\
\hline 1.66 & 12 & 1.77 & 10 & 1.59 & 40 \\
\hline 1.59 & 30 & 1.58 & 15 & 1.58 & 45 \\
\hline 1.57 & 20 & 1.54 & 30 & 1.57 & 80 \\
\hline 1.53 & 65 & 1.53 & 35 & 1.53 & 75 \\
\hline 1.49 & 25 & 1.50 & 25 & 1.50 & 30 \\
\hline- & - & 1.47 & 10 & 1.45 & 40 \\
\hline- & - & 1.45 & 10 & 1.43 & 40 \\
\hline
\end{tabular}

results can be summarized as given below:

$$
\alpha-\mathrm{Cu}_{3} \mathrm{~V}_{2} \mathrm{O}_{8} \underset{435^{\circ} \mathrm{C}}{\stackrel{510^{\circ} \mathrm{C}}{\rightleftharpoons}} \beta-\mathrm{Cu}_{3} \mathrm{~V}_{2} \mathrm{O}_{8} \underset{535^{\circ} \mathrm{C}}{\stackrel{545^{\circ} \mathrm{C}}{\rightleftharpoons}} \gamma-\mathrm{Cu}_{3} \mathrm{~V}_{2} \mathrm{O}_{8}
$$

The structural transitions of $\mathrm{Cu}_{3} \mathrm{~V}_{2} \mathrm{O}_{8}$ are reminiscent of $\mathrm{Zn}_{3} \mathrm{~V}_{2} \mathrm{O}_{8}$ (Brown and Hummel 1965).

The crystal structure of $\mathrm{Cu}_{3} \mathrm{~V}_{2} \mathrm{O}_{8}$ is similar to those of $\mathrm{Mg}_{3} \mathrm{~V}_{2} \mathrm{O}_{8}$ (Calvo and Krishnamachari 1971), $\mathrm{Zn}_{3} \mathrm{~V}_{2} \mathrm{O}_{8}$ (Calvo and Gopal 1971) and $\mathrm{Co}_{3} \mathrm{~V}_{2} \mathrm{O}_{8}$ and $\mathrm{Ni}_{3} \mathrm{~V}_{2} \mathrm{O}_{8}$ (Calvo et al 1973). These orthovanadates crystallize with crystal structure orthorhombic space group cmca. In general, these orthovanadate structures are based on pseudocubic arrangement of close packed layers of oxygen atoms. The oxygen layers alternate between pairs containing tetrahedrally coordinated $\mathrm{V}^{5+}$ ions. All the cations (except $\mathrm{Cu}_{3} \mathrm{~V}_{2} \mathrm{O}_{8}$ ) have nearly regular octahedral coordination. Figure 3 shows a perspective view of $\mathrm{Cu}_{3} \mathrm{~V}_{2} \mathrm{O}_{8}$ monoclinic, $P 2_{1} / C$ projected along the $C$-axis (Calvo and Shannon 1972). In this lattice, $\mathrm{Cu}^{2+}$ is found to occupy two octahedral sites $\mathrm{Cu}(1)$ and $\mathrm{Cu}(2)$. It can be noted from the above structure that the chains of edge sharing $\mathrm{Cu}(2)$ octahedra run along the $c$-axis with $\mathrm{Cu}(1)$ octahedra sharing two 

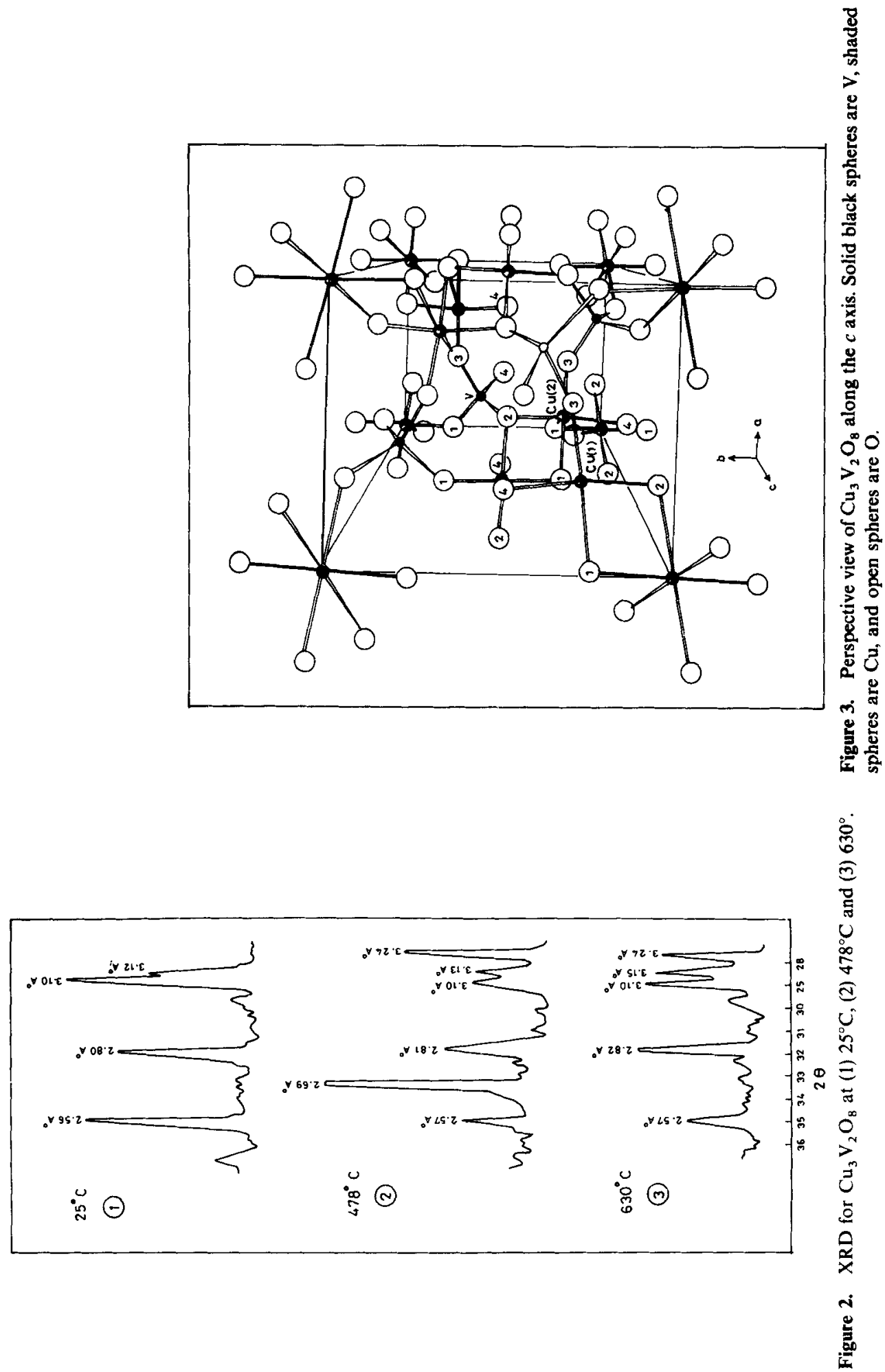
edges with $\mathrm{Cu}(2)$ octahedra, as shown in figure 3. These $\mathrm{Cu}(2)-\mathrm{O}_{6}$ octahedral networks are linked by corner shared $\mathrm{VO}_{4}$ tetrahedra. The distortion from the orthorhombic (space group cmca) crystal structure, $\mathrm{M}_{3} \mathrm{~V}_{2} \mathrm{O}_{8}$ [where $\mathrm{M}=\mathrm{Mg}^{2+}, \mathrm{Zn}^{2+}, \mathrm{Co}^{2+}$ or $\mathrm{Ni}^{2+}$ ], to crystal symmetry monoclinic $P 2_{1} / C$ of $\mathrm{Cu}_{3} \mathrm{~V}_{2} \mathrm{O}_{8}$ was explained on the basis of the $\mathrm{J}-\mathrm{T}$ effect of $\mathrm{Cu}^{2+}$ ions in the lattice of $\mathrm{Cu}_{3} \mathrm{~V}_{2} \mathrm{O}_{8}$, which resulted in four short and two long $\mathrm{Cu}-\mathrm{O}$ bonds of the octahedra.

It can be concluded from the above experimental results of DTA and high temperature $\mathrm{XRD}$ that $\mathrm{Cu}_{3} \mathrm{~V}_{2} \mathrm{O}_{8}$ has two high temperature forms in addition to the room temperature phase, and the crystal structures of these $\mathrm{Cu}_{3} \mathrm{~V}_{2} \mathrm{O}_{8}$ phases are related to the structure of $\mathrm{M}_{3} \mathrm{~V}_{2} \mathrm{O}_{8}$ (where $\mathrm{M}=\mathrm{Mg}^{2+}, \mathrm{Zn}^{2+}, \mathrm{Co}^{2+}$ or $\mathrm{Ni}^{2+}$ ).

\section{Acknowledgements}

The authors sincerely thank the UGC for providing the research grant for this investigation and also express their gratitude to Chemical Division, Bhabha Atomic Research Centre, Bombay, for obtaining the high temperature XRD of the samples.

\section{References}

Brisi C and Molinari A 1958 Ann. Chim. 48263

Brown J J and Hummel F A 1965 Trans. Br. Ceram. Soc. 64419

Calvo C and Gopal R 1971 Canadian J.Chem. 493056

Calvo C and Krishnamachari N 1971 Canadian J.Chem. 491629

Calvo C, Sauerbrei E E and Faggiani R 1973 Acta Crystallogr. B29 2304

Calvo C and Shannon R D 1972 Canadian J.Chem. 503944

Fluery P 1966 C. R. Acad. Sci. Paris C253 1375

Fluery P 1969 Rev. Chem. Miner. 6819

Galy J 1976 (Private communication)

Palanna O G and Suresh Rao N 1993 Bull. Mater. Sci. 1637

Raveau B 1967 Rev. Chem. Miner. 4729

Riassento 1958 Ann. Chim. (Rome) 48263 